\title{
Playful Work Design: Introduction of a New Concept
}

\author{
Arnold B. Bakker (D), Yuri S. Scharp (D), Kimberley Breevaart (iD and Juriena D. de Vries \\ Center of Excellence for Positive Organizational Psychology, Erasmus University Rotterdam (The Netherlands)
}

\begin{abstract}
This article introduces the concept of playful work design-the process through which employees proactively create conditions within work activities that foster enjoyment and challenge without changing the design of the job itself. First, we review play theory and the motives people may have to play during work. In addition, we use the literature on proactive work behavior to argue that individuals can take personal initiative to increase person-job fit. Combining these literatures, we provide a theoretical framework for playful work design. We discuss the development and validation of an instrument to assess playful work design, and review recent studies to elucidate the psychological effects of playful work design and its possible outcomes. Finally, we briefly discuss practical implications.
\end{abstract}

Received 16 March 2020; Revised 8 May 2020; Accepted 11 May 2020

Keywords: JD-R theory, playfulness, playful work design, proactive work behavior, work engagement

\section{Playful Work Design: Introduction of a New Concept}

Work is an important source of meaning in many people's lives, but what if work involves repetitive, monotonous, or tedious activities? How do tour operators who do the same tour every day stay engaged in their work? What can food delivery workers do to stay vigorous while trying to make as many deliveries as possible in the shortest time? How can office workers continue to work happily when they receive huge numbers of e-mails each day? In this article, we argue that play is an important driver of work motivation, and that individuals in a wide range of jobs may proactively design their work to be playful in order to feel invigorated and enthusiastic (i.e., work engaged).

The central aim of this article is to introduce the concept of "playful work design"-the process of employees proactively creating conditions during work that foster enjoyment and challenge without changing the job itself (Bakker \& van Woerkom, 2017; Scharp et al., 2019). First, we discuss play theory and the motives people may have to play during work. Second, we use the literature on proactive work behavior to argue that individuals can take personal initiative to change their situation or themselves to improve their work experience. Third, we combine the literatures on

Correspondence concerning this article should be addressed to Arnold B. Bakker, Erasmus University Rotterdam, Center of Excellence for Positive Organizational Psychology, Woudestein Campus, Mandeville Building T13-47, PO Box 1738. 3000 DR Rotterdam (The Netherlands). Phone: +31-104088853.

E-mail: bakker@fsw.eur.nl

Conflicts of Interest. None.

This research received no specific grant from any funding agency, commercial or not-for-profit sectors. play and proactive work behavior to introduce the concept of playful work design. In addition, we discuss the development and validation of an instrument to assess playful work design. Moreover, we review several recent studies to elucidate the psychological effects of playful work design and its possible outcomes. Finally, we briefly discuss practical implications.

\section{Play during Work}

According to van Vleet and Feeney (2015), play is an activity or behavior with three core features. The first essential aspect of play is that the activity is carried out with the goal of fun and/or challenge (e.g., Csikszentmihalyi, 1975; Mainemelis \& Ronson, 2006). The focus on fun and challenge explains why play activities are often voluntary and process-focused, and why individuals are intrinsically motivated to engage in play (Petelczyc et al., 2018). The second feature of play is that it requires an enthusiastic and in-the-moment attitude. When individuals play, they detach from outside stressors and become completely absorbed in the activity (Csikszentmihalyi, 1975; Huizinga, 1949). The third essential element of play is that the activity is highly interactive (van Vleet \& Feeney, 2015). This interaction may occur with the activity itself or with other persons who participate in the activity. Thus, enjoyable and absorbing activities that are passive and do not require personal initiative - such as reading a book or watching

How to cite this article:

Bakker, A. B., Scharp, Y. S., Breevaart, K., \& de Vries, J. D. (2020).

Playful work design: Introduction of a new concept. The Spanish Journal of Psychology, 23. e19. Doi:10.1017/SJP.2020.20 
TV-are not considered to be play (Petelczyc et al., 2018). Conversely, a game of solitaire (i.e., individual) as well as banter between two friends (i.e., interpersonal) are both highly interactive activities where the player may initiate a wide variety of actions. The literature generally describes two types of play: ludic and agonistic play. Ludic play is playful, arbitrary, and irrational, and focuses on the use of humor and imagination such as role-play, lighthearted teasing, and joking (e.g., Barnett, 2007; Martin \& Ford, 2018). In contrast, agonistic play is more serious, rational, and rule-bound. Agonistic play focuses on challenges and rules such as in sports, games, and competition (e.g., Abramis, 1990; Csikszentmihalyi, 1975).

Employees may have several motives to engage in play at work. First, Petelczyc et al. (2018) defined play as stimulus-seeking behavior, where people avoid boredom and increase enjoyment by raising their level of stimulation. Second, Csikszentmihalyi (1975) argued that individuals are intrinsically motivated to seek playful activities (e.g., rock climbing, dancing, playing chess) that balance challenge with some level of skill. Such activities may result in "flow" — creating a sense of control as well as a loss of self-consciousness. Third, the cathartic perspective of play proposes that engaging in play provides a person with relief (DesCamp \& Thomas, 1993). Here, play is a means to recuperate from the job demands employees are exposed to. Fourth and finally, social and cognitive processing perspectives of play during work (e.g., Webster \& Martocchio, 1993) contend that labeling and framing work tasks as play could improve one's task performance, because play has a more positive connotation than work. Labeling a work task as play may therefore improve one's attitude toward, and consequently the amount of effort spent on, that task.

Research has indeed shown that engaging in play has important implications for the work experience, as suggested by the abovementioned motives. Play has been shown to reduce boredom when confronted with monotonous work (Roy, 1959). Play has also been shown to increase job satisfaction and perceptions of competence (Abramis, 1990), and reduce job stress and burnout (e.g., DesCamp \& Thomas, 1993). These findings raise the question whether employees can proactively change the experience of their work by making their work more playful. In this way, they may be able to increase the meaning of work and improve their wellbeing. We will first discuss the needed proactive work behavior, and then turn to playful work design.

\section{Proactive Work Behavior}

When people are proactive, they challenge the status quo rather than passively adapting to existing conditions (Crant, 2000). Proactive individuals take the initiative to improve their current circumstances-they envision and plan a different future by changing the self or the environment (Parker \& Collins, 2010). Examples of proactive behavior at work are taking charge to improve work methods, proactive feedback-seeking, negotiating a customized employment arrangement, and proactive problem-solving. Recent studies have shown that employees also proactively optimize their vitality (the "self") by consciously engaging in activities that make them feel energized and motivated, for example, by regularly taking a walk, drinking coffee and socialize, or using the stairs at work (Op den Kamp et al., 2018). Moreover, the last decade has seen a sharp increase in the number of studies on job crafting, which concerns employees taking the initiative to change their personal job characteristics (Rudolph et al., 2017).

Job Demands-Resources theory (Bakker \& Demerouti, 2017) outlines when employees have a good reason to engage in proactive work behavior. A central proposition in the theory is that employees feel particularly stressed when continuously exposed to high levels of job demands (i.e., aspects of work that ask for considerable effort) combined with low levels of job resources (i.e., aspects of work that help to reach work goals, and stimulate personal growth). In contrast, employees feel bored when an abundance of job resources is paired with insufficient challenges (Bakker \& Oerlemans, 2011). In both situations, employees have ample reason to proactively change the meaning of their work and improve their work-related well-being. This can be done by (a) proactively engaging in activities that are energizing (proactive vitality management); (b) proactively optimizing the job demands or resources (job crafting); or (c) proactively changing one's approach of work and thereby the accompanying experience (playful work design).

\section{Playful Work Design}

Playful work design refers to the process through which employees proactively create conditions within work activities that foster enjoyment and challenge without changing the design of the job itself (Bakker \& van Woerkom, 2017). Through playful work design, employees optimize the personal experience of work. Following the duality of play, they may do so in two different ways. First, employees may engage in ludic play and make the work activity more fun, for example, by reframing a work situation to provide oneself and others with amusement (Barnett, 2007). Second, employees may use agonistic play, and playfully design their work by creating a form of competition with themselves, for example, by trying to beat the clock when performing a task. By making work activities more playful, individuals may increase their intrinsic 
motivation and creativity (Mainemelis \& Ronson, 2006), create a sense of belongingness (Sandelands, 2010), and stimulate energetic performance (Barnett, 2007).

In interviews and workshops, we asked employees what they do to make their work more playful. One accountant said: "I try to reduce the number of emails by sending one e-mail less than the day before-and I do this every day." A pilot told: "I often try to save fuel by trying to minimize the impact of winds, turbulence, and other natural conditions that require my plane to use additional fuel. I also try to find out what the best practices are for flying into and out of airports." An HR manager indicated: "When I need to work on a boring, bureaucratic task, I make it playful by building additional tasks into the boring task. One option is to fill out the form using the fewest words possible yet covering all the content that must be addressed. This makes it a writing challenge and as such, more interesting."

Playful work design originates from the synergy between the playfulness and proactive work behavior literatures. Playfulness refers to the ability to transform almost any situation into one that is amusing and entertaining (Barnett, 2007). According to Petelczyc et al. (2018), individuals have several motives to play at work, such as (a) avoiding boredom, (b) increasing flow, and (c) decreasing job stress. Proactive work behavior involves self-initiated, anticipatory action aimed at changing either the situation or oneself (Bindl \& Parker, 2010). Examples include taking charge to improve work methods, proactive feedback-seeking, and proactive problem-solving. Employees who design their work to be more playful take personal initiative to make their work tasks more fun and/or competitive. By making their tasks more playful, employees redesign their work activities to be more engaging, entertaining, and meaningful. Similar to job crafting, playful work design may make work activities more challenging. However, there are important differences. Job crafting refers to proactively seeking new job resources (e.g., asking for feedback and support), and actively searching for new tasks and projects that are different from the work the employee is already involved in. Playful work design refers to the proactive, behavioral work orientation that designs fun and competition by imposing the experiential qualities of play on existing work (Scharp et al., 2019). Cognitive crafting is more closely related to playful work design than other forms of job crafting due to its focus on reframing. However, whereas cognitive crafting refers to expanding the perception of task boundaries or focusing perceptions on tasks that are most meaningful (Berg et al., 2013), playful work design refers to proactively changing the experience of work activities by designing these activities to be more fun or more competitive.
Our research suggests that playful work design may be applied to various work tasks, especially tasks that are repetitive, monotonous, and tedious. Although some work tasks seem at first glance less appropriate for playful work design (e.g., surgery by a surgeon), they may still be appropriate for playful work design. Csikszentmihalyi (1975, p. 156) quoted an eye surgeon, who illustrated that imagination may help to even be playful during surgery, "You use fine and precise instruments. It is an exercise in art. ... It all rests on how precisely and artistically you do the operation." However, playful work design may be undesirable or inefficient when work tasks are severely cognitively taxing or already fun and challenging (e.g., therapy session by a psychiatrist; writing an article by a scientist). Interestingly, the concept of playful redesign may also be applicable to activities outside the work domain. For example, study activities and sports trainings arefrom a psychological perspective-comparable with work. Study and sport/exercise are also structured, goal-directed, time demanding, and to a large extent obligatory, and both domains may be excellent areas for playful design.

\section{The Measurement of Playful Work Design}

A new questionnaire to measure playful work design was developed using an inductive approach (Scharp, Bakker, et al., 2020). We used the input from participants in playful work design workshops to generate 200 items. In the next step, experts selected items that best reflected playful work design (PWD), resulting in 32 items, which were tested in two samples from various occupations $(N=428, N=302)$. This resulted in a twelve-item and two-dimensional instrument, including items such as "I look for ways to make my work more fun," and "I approach my tasks creatively to make them more interesting" (Designing Fun); and "I try to set time records in my work tasks," and "I compete with myself at work, not because I have to, but because I enjoy it" (Designing Competition). The internal consistencies of the subscales were satisfactory, with Cronbach's alpha coefficients of .75 and .80 for Designing Fun, and .73 and .75 for Designing Competition. The two-factor solution fitted well to the data in both samples, and outperformed a one-factor model, indicating a robust factor structure.

In support of convergent validity, employees high in personal initiative, curiosity, openness, playfulness, humor, creative personality, competitiveness, achievement striving, and imagination, and low in rigidity were more likely to engage in playful work design (Scharp, Bakker, et al., 2020). In addition, playful work design was more prevalent in work environments characterized by higher levels of autonomy and more support for 
fun. Nonetheless, the authors argue that PWD operates relatively independently of job characteristics. Due to the inherent cognitive nature of PWD, individuals may playfully design their work in a wide variety of settings. For instance, while bus drivers lack autonomy regarding their routes, they may frame every ride as a game with the goal of the least number of deaccelerations. Thus, playful work design is a bottom-up strategy that is initiated by the employee. Having said that, it is still possible that organizations facilitate playful work design (i.e., top-down), for example, by supporting autonomy and by offering trainings. In support of the two-factor structure and divergent validity, designing fun correlated more strongly with ludic traits (i.e., playfulness, humor, and creative personality) than designing competition, whereas designing competition correlated more strongly with agonistic traits (i.e., competitiveness and achievement striving) than designing fun. Furthermore, playful work design was weakly negatively related (or unrelated) to procrastination, cynicism, and laziness, and positively related to work engagement. These findings show that employees are more likely to show playful work design when they have playful and proactive tendencies, which helps them to be enthusiastically involved in their work.

\section{More Empirical Evidence from Diary Studies}

Since playful work design is linked to specific tasks, it fluctuates substantially within the course of a day and from one day to the other. In order to investigate under what conditions this proactive behavior is most effective, we conducted three quantitative diary studies.

In a first study, we investigated whether daily playful work design would be most effective for employees with a playful and open personality (Scharp et al., 2019). According to trait activation theory, employees intrinsically enjoy conditions at work that satisfy the stable personal needs that are rooted in their personality (Tett \& Burnett, 2003). Therefore, they will seek out work situations that activate their traits. The results of the study showed that employees were more engaged in their work and more creative on the days when they used more playful work design. Moreover, the impact of playfully designing work to be more fun was stronger for individuals high in openness, and the impact of playfully designing work to be more competitive was stronger for individuals high in playfulness. These findings support the contention that employees who are high in openness to experience and playfulness profit most from playful work design.

In a second study (Scharp, Breevaart, et al., 2020), we tried to find out whether playful work design can be used to proactively deal with daily hindrance job demands, i.e., work tasks and conditions that require effort and energy, but do not have growth potential (Lepine et al., 2005). We hypothesized that employees may design fun to cope with emotionally draining work, and design competition to deal with effortless and unchallenging work. The findings revealed that employees were less engaged and performed more poorly (e.g., lower in-role and extra-role performance) on the days when they were confronted with both types of hindrance demands. However, as predicted, emotionally draining work undermined employees' enthusiasm and energy to a much lower extent on the days when they proactively designed their work to be more fun. In addition, effortless and unchallenging work reduced work engagement substantially less on the days when employees proactively designed their work to be more competitive. These findings clearly show that playful work design can be used to protect employees' work engagement and performance.

In the third diary study (Bakker et al., 2020), we examined the predictive validity of playful work design vis-à-vis job crafting, and also investigated when both proactive behaviors were most effective. We hypothesized that individuals perform better on the days when they seek job resources and challenges, reduce job demands, or design their work to be playful. In addition, we argued that seeking resources and reducing demands would be most effective when work pressure is high, and that the stimulus-seeking behaviors of increasing challenges and playful work design would be most effective when work pressure is low. The results showed that seeking job resources, seeking challenges, and playful work design were all positively related to colleague-ratings of job performance. However, reducing job demands was negatively related to performance. As hypothesized, seeking challenges and playful work design were most effective when work pressure was low rather than high.

\section{Practical Implications}

Our research reveals that employees use playful work design for a wide range of tasks, and that this behavior fluctuates from day to day. In addition, the findings suggest that playful work design has important consequences for practice since it impacts employee work engagement and performance. The playful work design measure could be used in organizations to assess the prevalence of this proactive behavior, and find employees who approach their work most playfully. By interviewing employees who are naturally best at designing work to be playful, organizations can get more insight into the various ways through which employees may redesign their tasks and activities. This seems particularly important in organizations where hindrance demands are high, and work pressure is 
low. The examples of playful work design collected in interviews may then be used in training interventions to teach other employees how they may optimize their work experience in order to stay engaged and perform well. The training intervention should ideally be combined with goal setting and/or coaching to help employees implement their new work design strategies in daily practice.

\section{Conclusion}

People have a natural tendency to play, because play is intrinsically rewarding and satisfying. Building on this principle, we propose that employees may proactively create playful work by designing elements of fun and competition in their work tasks. The first studies on playful work design indicate that this proactive behavior has positive consequences for employee well-being, creativity, and performance-particularly for individuals with an open and playful personality. Playful work design makes the work intrinsically motivating and helps to deal with draining and tedious tasks. We hope that this article will stimulate future research on playful work design as well as practical applications.

\section{References}

Abramis, D. J. (1990). Play in work: Childish hedonism or adult enthusiasm? American Behavioral Scientist, 33, 353-373. http:/ / doi.org/10.1177/0002764290033003010

Bakker, A. B., \& Demerouti, E. (2017). Job demands-resources theory: Taking stock and looking forward. Journal of Occupational Health Psychology, 22, 273-285. http: / / doi.org/ 10.1037 / ocp0000056

Bakker, A. B., Hetland, J., Kjellevold Olsen, O., Espevik, R., \& de Vries, J. D. (2020). Job crafting and playful work design: Links with performance during busy and quiet days. [Manuscript submitted for publication]. Center of Excellence for Positive Organizational Psychology, Erasmus University Rotterdam.

Bakker, A. B., \& Oerlemans, W. (2011). Subjective well-being in organizations. In K. Cameron \& G. Spreitzer (Eds.), Handbook of positive organizational scholarship (pp. 178-190). Oxford University Press.

Bakker, A. B., \& van Woerkom, M. (2017). Flow at work: A self-determination perspective. Occupational Health Science, 1, 47-65. http: / / doi.org/10.1007/s41542-017-0003-3

Barnett, L. A. (2007). The nature of playfulness in young adults. Personality and Individual Differences, 43, 949-958. http:/ / doi.org/10.1016/j.paid.2007.02.018

Berg, J. M., Dutton, J. E., \& Wrzesniewski, A. (2013). Job crafting and meaningful work. In B. J. Dik, Z. S. Byrne, \& M. F. Steger (Eds.), Purpose and meaning in the workplace (pp. 81-104). American Psychological Association. https:// doi.org/10.1037/14183-005

Bindl, U. K., \& Parker, S. K. (2010). Proactive work behavior: Forward-thinking and change-oriented action in organizations. In S. Zedeck (Ed.), APA handbook of industrial and organizational psychology: Vol 2. Selecting and developing members for the organization (pp. 567-598). American Psychological Association.

Crant, J. M. (2000). Proactive behavior in organizations. Journal of Management, 26, 435-462. http:/ / doi.org/10.1177/ 014920630002600304

Csikszentmihalyi, M. (1975). Beyond boredom and anxiety: The experience of play in work and games. Jossey-Bass.

DesCamp, K. D., \& Thomas, C. C. (1993). Buffering nursing stress through play at work. Western Journal of Nursing Research, 15, 619-627. https:/ / doi.org/10.1177/ 019394599301500508

Huizinga, J. (1949). Homo ludens: A study of the play-element in culture. Routledge \& Kegan Paul.

Lepine, J. A., Podsakoff, N. P., \& Lepine, M. A. (2005). A metaanalytic test of the challenge stressor-hindrance stressor framework: An explanation for inconsistent relationships among stressors and performance. Academy of Management Journal, 48, 764-775. http:/ / doi.org/10.5465/ amj.2005.18803921

Mainemelis, C., \& Ronson, S. (2006). Ideas are born in fields of play: Towards a theory of play and creativity in organizational settings. Research in Organizational Behavior, 27, 81-131. https: / / doi.org/10.1016/S0191-3085(06)27003-5

Martin, R. A., \& Ford, T. (2018). The psychology of humor: An integrative approach. Elsevier Academic Press.

Op den Kamp, E. M., Tims, M., Bakker, A. B., \& Demerouti, E. (2018). Proactive vitality management in the work context: Development and validation of a new instrument. European Journal of Work and Organizational Psychology, 27, 493-505. http:/ / doi.org/10.1080/1359432X.2018.1483915

Parker, S. K., \& Collins, C. G. (2010). Taking stock: Integrating and differentiating multiple proactive behaviors. Journal of Management, 36, 633-662. http:/ / doi.org/10.1177/ 0149206308321554

Petelczyc, C. A., Capezio, A., Wang, L., Restubog, S. L. D., \& Aquino, K. (2018). Play at work: An integrative review and agenda for future research. Journal of Management, 44, 161-190. http:/ / doi.org/10.1177/0149206317731519

Roy, D. (1959). Banana time job-satisfaction and informal interaction. Human Organization, 18, 158-168. http: / / doi.org/10.17730/humo.18.4.07j88hr1p4074605

Rudolph, C. W., Katz, I. M., Lavigne, K. N., \& Zacher, H. (2017). Job crafting: A meta-analysis of relationships with individual differences, job characteristics, and work outcomes. Journal of Vocational Behavior, 102, 112-138. http: / / doi.org/10.1016/j.jvb.2017.05.008

Sandelands, L. (2010). The play of change. Journal of Organizational Change Management, 23, 71-86. http:/ / doi.org/10.1108/09534811011017216

Scharp, Y. S., Bakker, A. B., Breevaart, K., Kruup, K., \& Uusberg, A. (2020). Playful work design: Conceptualization, measurement, and validity [Manuscript submitted for publication]. Center of Excellence for Positive Organizational Psychology, Erasmus University Rotterdam.

Scharp, Y. S., Breevaart, K., \& Bakker, A. B. (2020). Daily playful work design: Negating hindrance job demands and promoting work performance [Manuscript submitted for publication]. Center of Excellence for Positive Organizational Psychology, Erasmus University Rotterdam. 
Scharp, Y. S., Breevaart, K., Bakker, A. B., \& van der Linden, D. (2019). Daily playful work design: A trait activation perspective. Journal of Research in Personality, 82, Article 103850. http:/ / doi.org/10.1016/j.jrp.2019.103850

Tett, R. P., \& Burnett, D. D. (2003). A personality trait-based interactionist model of job performance. Journal of Applied Psychology, 88, 500-517. http:/ / doi.org/10.1037/00219010.88.3.500 van Vleet, M., \& Feeney, B. C. (2015). Young at heart: A perspective for advancing research on play in adulthood. Perspectives on Psychological Science, 10, 639-645. http:/ / doi.org/10.1177/1745691615596789

Webster, J., \& Martocchio, J. J. (1993). Turning work into play: Implications for microcomputer software training. Journal of Management, 19, 127-146. https:/ / doi.org/10.1016/01492063(93)90049-S 